\title{
Women's Fashion in Dalmatia at the End of the 18th Century
}

\author{
Katarina Nina Simončič
}

\section{Introduction}

This chapter aims to define the role of fashion garments as indicators of social status and a highly important aspect of visual communication among the social elites in 18th-century Dalmatia. The focal point of this overview is women's fashion. To achieve this goal, through research of historical artefacts from the Dalmatian territory, it is essential to address first the availability of sources and to explain possible problems we encountered in our attempt to reconstruct and comprehend particular historical circumstances. While preserved fashion artefacts of the privileged social class in 18th-century Dalmatia are very scarce, garments that belonged to lower classes are unavailable and can only be reconstructed from observations of travel writers or from court records. Certain fashion garments and accessories of the upper classes are currently preserved in museums in Zagreb, Split, Zadar, Sibenik and Dubrovnik. These include two women's jackets made of red and blue silk with gold and silver bobbin lace trimmings, which belonged to the Kasandric family on the island of Hvar; fans; lace artefacts and footwear. A larger and more substantial collection of menswear is preserved in the Rector's Palace in Dubrovnik. Since preserved artefacts are scarce and rarely found, they cannot provide sufficient information to reconstruct the social climate of the 18th century, when garments, i.e. fashion, functioned as a status symbol.

Historical records prove the continuity of a rich cultural life in Dalmatia from the Renaissance to the 18th century. In developed coastal cities with an active social life, society comprised of the nobility, the middle class, and the commoners. ${ }^{1}$ The financial superiority of the upper class was manifested through clothing and accessories, even though sumptuary laws, which also applied to the lower social classes, restricted private expenditure. Keeping up with the fashion styles of European capitals was an imperative for the upper

1 Danica Božić Bužančić, Privatni i društveni život Splita u osamnaestom stoljeću [The Private and Social Life of Split in the 18th Century] (Zagreb: 1982). 
classes and archival records provide evidence of intensive trade and presence of fashion styles, expensive fabrics, and fashion accessories. However, frequent conquests of the Dalmatian territory over the course of history by the French, the Republic of Venice, and the Habsburg Monarchy contributed to the disappearance and theft of fashion artefacts, which would later be housed in foreign museums or private collections under different owners' names.

In addition to fashion artefacts, liturgical vestments of this period are also an important source of information, which helps deepen our understanding of 18th-century fashion. Like the majority of fashion outfits of that period, these were made from the most expensive French fabric and manifested the beauty of fashion garments. Most vestments were made of textiles purchased for that very purpose or from fabrics given to the church by rich families and the nobility as votive offerings for prayers for the deceased. ${ }^{2}$

Monastery collections of lace in the Dalmatian region represent another important source. These testify to intensive manufacturing of lace intended for the 18th-century European market, which was mainly conducted on the islands of Pag and Hvar, as well as in Dubrovnik and Kotor. Records show that a lacemaker from the island of Pag was brought to Maria Theresa's Habsburg court for the purpose of making lace garments, accessories, and decorations. ${ }^{3}$

Apart from preserved fashion artefacts, attention should be paid to portraits and archival records as secondary sources, to enable a better comprehension of the fashion environment in that period. However, the terminology used should be approached with caution because it is difficult to understand with absolute precision the fashion nomenclature from the end of the 18th century. For instance, archival records contain Italian, French, and English terms which do not necessarily denote the same garment or fashion style in Dalmatia as they do in the country of origin. As far as the reliability of sources is concerned, this article attempts to reconstruct garments and accessories worn by women of the middle classes and the nobility in 18th-century Dalmatia.

2 Silvija Banić, "Prilog poznavanju sakralnih inventara otoka Raba: najvrjedniji povijesni tekstili sačuvani na misnom ruhu i drugim dijelovima liturgijske opreme" [Contributions to the Uunderstanding of the Sacred Inventory from Tthe Island of Rab: the Most Valuable Historical Textiles Preserved as Mass Attire and Other Parts of the Liturgical Equipment], Rapski zbornik II [Rab Almanac II] (Rab: 2012), 461-499.

3 Nerina Eckhel, Lacemaking in Croatia (Zagreb: 2007). 


\section{Trade Routes, Supply of Goods and Historical Circumstances in 18th-Century Dalmatia}

The territory of 18 th-century Dalmatia was at the intersection of eastern and western trade routes, thereby assimilating elements of both civilizations. ${ }^{4}$ However, fashion influences arriving from European capitals such as Paris, London and Vienna, as well as from Italian cities, through land and maritime trade routes, were dominant. Trade in the territory of Dalmatia was mainly concentrated in two coastal cities: Split and Dubrovnik. ${ }^{5}$

Over the course of the 18th century, trade routes across what is now presentday Dalmatia were simultaneously passing through the territories under the jurisdiction of the Republic of Venice (Istria, Dalmatia, and Albania-Boka), the Kingdom of Croatia, and the independent territory of the Republic of Ragusa (Fig. 3.1). Until the fall of the Republic of Venice in 1797, littoral Croatia was under the strong influence of Italy, whereas the southern part of the coast, along with the northern and eastern parts of the country, exhibited mainly French fashion influences arriving through Austria. ${ }^{6}$ Maria Theresa, the sovereign of the Habsburg Monarchy, played a prominent role in economic, politi$\mathrm{cal}$, and cultural development. Situated at the intersection of intensive eastern and western trade routes, with its two large ports of Split and Dubrovnik, Dalmatia was basically at the very centre of fashion exchanges between the new trends coming from the West and the exotic offerings arriving on the European market from the East. In the second half of the 18th century, fashion trends in America, Europe, and the colonies were set by the two global market leaders, England and France.

Tradeing in Dalmatia was chiefly conducted by Muslim merchants in the first half of the 18th century and by Jewish merchants in the second half. The port of Split developed in the 16th century, becoming one of the most important trading points between the Ottoman Empire and the Venetian Republic, particularly in the trade of fabrics. The Ottoman merchants used

4 Fernand Braudel, Civilization and Capitalism, 15th-18th Centuries, 1: The Structures of Everyday Life (London: 1981).

5 Grgo Novak, Split u svjetskom prometu [Split as a Part of World Traffic] (Split: 1930), Grgo Novak, Povijest Splita [The History of Split] (Split: 1964). Đivo Bašić, "Pomorstvo Dubrovnika od XII. do početka XX. Stoljeća" [The Maritime Affairs of Dubrovnik from the 12th to the Beginning of the 2oth Century], Pomorski zbornik 44 [Maritime Anali 44] (Dubrovnik: 2006) 1, 139-177.

6 Vladimir Marković, Ivana Prijatelj-Pavičić, Umjetnički dodiri dviju jadranskih obala u 17. i 18. stoljeću [Artistic Encounters Between Two Adriatic Coasts in the 17th and 18th Centuries] (Split: 2003). 


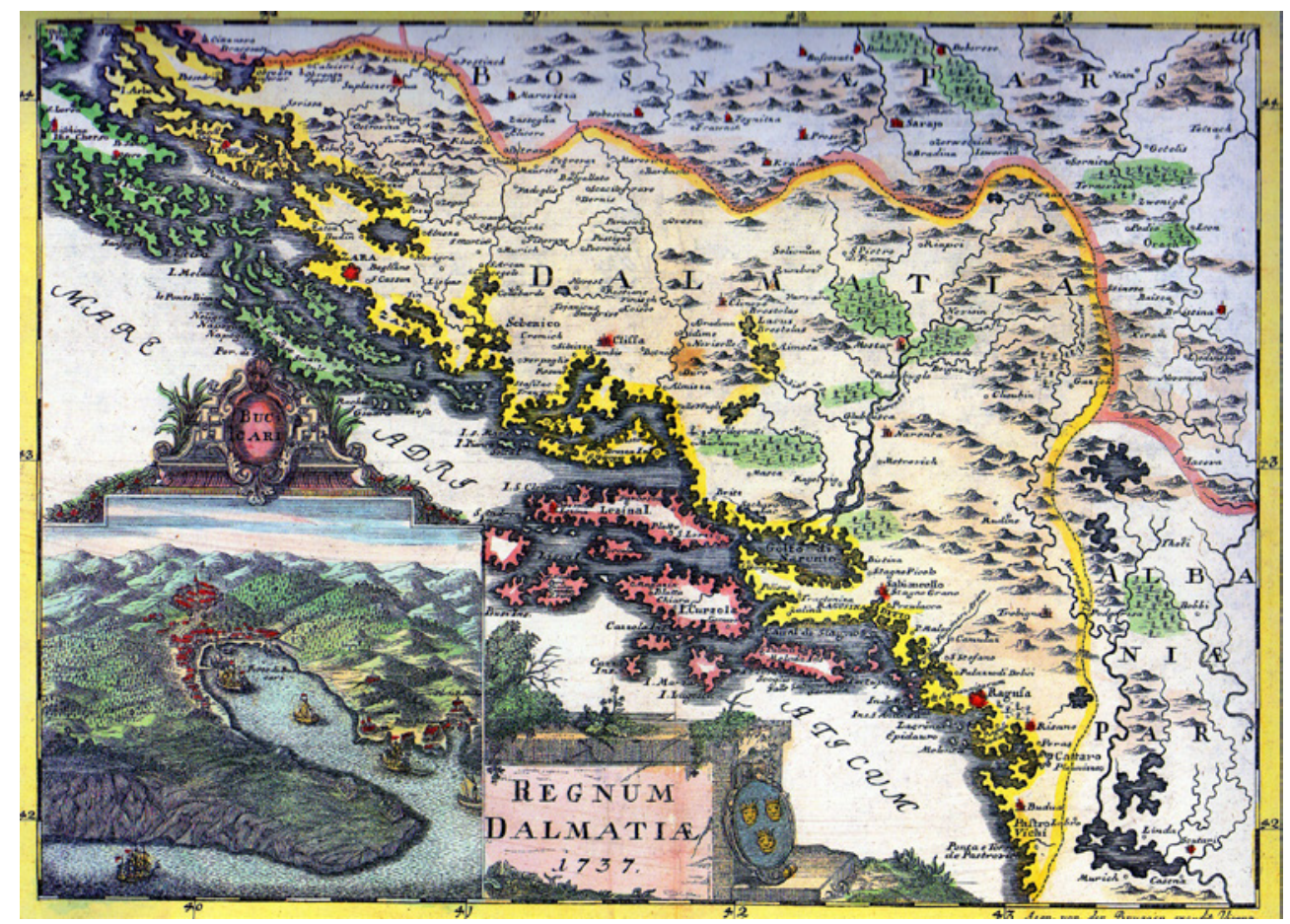

FIGURE 3.1 Johann Van Der Bruggen “REGNUM DALMATIAE 1737”, Vienna 1737.

land caravans to travel to Split via Bosnia and, from there, the goods were transported to Venice in ships. Since the Ottoman Empire decided to pave the road to Split, the journey from Istanbul to Split took 43 days. ${ }^{7}$ For instance, 18th-century Split received two or three caravans per day with hundreds of kilograms of goods loaded on horses. A list from around $175^{2-53}$ reveals goods shipped from Split to Venice and back. ${ }^{8}$ The specific names, such as silk romaneta, damashino canvas, shirt turchesca, and leather bulgaro indicate the origin of fabrics and patterns. ${ }^{9}$

7 Nataša Bajić-Žarko, Split kao trgovačko i tranzitno središte na razmeđu istoka i zapada u 18. stoljeću [Split as a Trade and Transit Centre at the Crossroads of East and West in the 18th Century] (Split: 2004), 89 .

8 Ibid., 90.

9 This commodities list dates from around $175^{2-1753}$. It refers to goods that arrived in Split and which were then sent to Venice: bambosina shirts; small silk tapes; large silk tapes; small and large buttons; silk shirts; boots; slippers; turchesca shirts; mahrame (bandanas of Turkish origin); turchesca fabrics with 4 buckles; belts; silk; leather: beaver, hare, ram, devilfish, ox, 
In assessing the significance of fashion and its role as an indicator of social status, written documents, such as trade and legal records, court settlements and testaments provide the principal source of information. Considering their numbers and the sequence in which they were recorded, these expensive, high-quality garments functioned as status symbols in the formation of the visual dress code of privileged individuals. Only high social classes could afford garments à la mode. The term à la mode referred to French (robe à la française) or English dresses (robe à l'anglaise), garments made of expensive cotton and silk in intense, yet pastel tones. Lower social classes wore clothes in white or matt tones, although they were often embroidered in bright colours and accessorized with jewellery. This term (à la mode) also referred to fashion accessories and decorations such as lace trimmings, silk ribbons and bows, braids, pearls and gemstones applied to ready-made dresses. Thanks to intensive trade practices and local production in monasteries, the use of lace for decoration was also common in Dalmatia and records show it was extensively manufactured in this territory. Attempts to trace Dalmatian lace and its uses in the production of fashion artefacts in European capitals are complicated by the fact that lace was mostly bought by Venetian merchants and later resold as Venetian lace. ${ }^{10}$ However, thanks to traders from Dubrovnik, Flemish lace was imported and sold along the entire Adriatic coast."1

Social segregation was also present among craftsmen and artisans: Croatian tailors made suits out of cheap fabrics, whereas German tailors sewed expensive suits for the middle class. Although there are records of many foreign and

old cats, wild cats, goat, lamb, calf, bear, rabbit, badger, camel, panther, jackal, bulgaro (fine leather from Bulgaria); wool: fine and medium fine, bleached, washed, shorn and rough wool, wool from Skadar, Skoplje, Sarajevo, Novi Pazar and Albania; red bombaso canvas; salonichio; unusual clothes; delo stato fabric; serž/londrini fabric; scarlet red fabric; zambeletto fabric; silk: fine, rough, for colouring, unclean, loose. Goods that came from Venice to Split: fine fabric with Kalanka patterning; calimani fabric; fine French silk; arrattine from England; spagniollett; tamina from France; kamelot from England; black silk with flower patterns; black brussellini from England; green fabric sempitterna landines from England. Fine French and English silk are frequently mentioned.

10 Nevenka Božanić-Bezić, "Prilog istraživanju čipke u Dalmaciji" [Contributions to the Research of Lace from Dalmatia], Središnji čipkarski tečaj u Beču [The Central Lacework Course in Vienna] (Lepoglava: 2002), 60-72. In the 17th and 18th century, Dalmatian lace was sold as "Venetian". A similar practice is observed in the zoth century, when it was sold as "Austrian".

11 Nevenka Božanić-Bezić, "Čipka na odjeći u 18. stoljeću u srednjoj Dalmaciji” [Lace on Clothing from the 18th Century in Dalmatia], Čipka u kulturi tekstila i odijevanja (Lepoglava: 2003), 10. 
domestic artisans in Split, such as hat makers, furriers, tailors and cobblers, ${ }^{12}$ affluent young women, especially brides-to-be, used to travel to Ancona and Venice for their attire, where they ordered tailored dresses and other decorative articles such as fans, gloves, scarves and purses. ${ }^{13}$ In Dalmatia, specific terms were used to denote merchants specialized in trading garments, textiles, and fashion accessories. Thus, mercator or trgovac, also in use, referred to wholesalers, while caupo or kramar stood for retailers; female fashion merchants were mercatorisae, whereas local and foreign merchants were called mercator domesticus or mercator extraneus, respectively. When denoting a narrow specialization in trading particular goods, the following terms were also used: sagarius for the merchant of ready-made clothes, metaxa for the merchant of silk and silk goods, manufacturarum negotiator for the merchant of fashionable goods and fabrics, and finally, hančomohar for a glove maker.

Haberdashery, i.e. small ware and trimmings, were made by specialized women fashion merchandisers (marchandes de modes). Their entry into the mid-18th-century fashion market introduced a revolutionary change in the historically established hierarchy of sexual division of labour. Les marchandes de modes, who specialized in garment-finishing, i.e. decorations and trimmings of ready-made women's and men's garments, joined the textiles and garmentmerchandizing market in which male tailors specialized in men's suits and female tailors in women's wear. ${ }^{14}$

While the market for garments and textiles provided an adequate supply of goods for middle-class consumers, Dalmatian noblewomen custom-ordered individually made garments or they and their families purchased fashion items during their official or private travels. ${ }^{15}$

The differences between clothes worn by members of different social classes were also regulated by sumptuary laws, which referred to both the fabrics and garments available to them. Thus, luxurious fabrics, intended solely for women of high society, were inaccessible to members of the lower social classes. ${ }^{16}$

\footnotetext{
12 Bajić-Žarko, Split, 164.

13 Rudolf Horvat, Kaptolski cehovi u Zagrebu [Kaptol Guilds in Zagreb] (Zagreb: 1936), 38; Slavko Stojan, U salonu Marije Giorgi Bona [In the Salon of Marija Giorgi Bona] (Dubrovnik: 1996), 115 .

14 Rudolf Horvat, Povijest trgovine obrta i industrije u Hrvatskoj [The History of Trades, Crafts and Industry in Croatia] (Zagreb: 1994), 56.

15 Ibid., 60.

16 Zdenka Janeković Römer, Nasilje zakona: Gradska vlast i privatni život u kasno srednjovjekovnom i ranonovovjekovnom Dubrovniku [The Violence of Law: City Authorities and Private Life in Medieval and Early Modern Dubrovnik] (Dubrovnika: 2003).
} 
On several occasions during the 18th century, sumptuary legislation limited the quantity of foreign luxury fabrics ${ }^{17}$ allowed to different consumers. ${ }^{18}$ When limitations were imposed, noblewomen hid their expensive fashionable clothes in chests, which would be inherited by the Church after their death. Laws against luxury clothes did not include church attire, therefore expensive fabric from fashionable clothes could be reused to make new garments.

The most evident difference in the appearance of noblewomen and their middle-class counterparts was in their jewellery. The former possessed jewellery made from precious gemstones, whereas the latter wore gold. Women from the lower social classes could only afford silver. Among middle-class women, jewellery was the most frequently-mentioned fashion accessory, particularly gold, filigree earrings, decorated with pearls, diamonds and coral. ${ }^{19}$ They were described as being mainly bell-shaped and of a cluster drop design. A mandatory accessory in the fashion inventory of middle-class women was a gold pendant chain which, along with a belt, indicated the family's financial status.

\section{Lace Production and Lace Items as Indicators of Social Status}

Lace trimmings, silk ribbons (bows), braids, and pearl and gem decorations, which were applied to ready-made dresses, became status symbols and mandatory accessories in achieving the desired à la mode look. Due to intensive

17 Trade supervisors labelled as "foreign goods" the so-called exotic merchandise. For that reason in 1774, Zagreb started using the stamp "L.R.C.Z" (e.g. Libera regia civitas Zagrabiensis); Zlatko Herkov, Povijest zagrebačke trgovine [The History of Trade in Zagreb] (Zagreb: 1987), 215 .

18 Quantity limitations: silk fabrics in purple and scarlet colour and other expensive colours, silk fabrics in inexpensive colours (blue, green, regular red), silk fabric of lower quality, good quality English fabrics in expensive colours, lower quality English fabrics in other colours, scarlet fabrics (scarlet and granat), silk fabrics from towns of Padua, Naples (gros de Tour, gros de Naples, croice Damast (Croisee), Damast or Procatelle (brocatelle, low quality brocade or their imitations) and rassette (type of satin), fabrics called kepentuh, maris, septuh, mornay, raseta, burset, quinet, capiczol, tabin, tabinet (from franc. tabisilk), boroszla (Bratislava fabric; hung. boroszloi), paja (flannel fabric) and tafunt (franc. tafetas, taffeta), pannus latus floret (franc. "fleuret", type of silk fabric) czinodo dictus, pannus latus perdonon (Bergam) vocatus and floretus simplex, lodus seu gausape-(tufted wool fabrics, ger. Loden e.g. rough Tirol cloth), konton and ziz ( Ciz-Cotten) - cotton fabric, Pfeffer bandana (germ. Pfeffer-Tüchel).

Nevenka Božanić-Bezić, Juditini dvori [Judith’s Chambers] (Split: 2001), 214. 
trade and abundant local production in monasteries, ${ }^{20}$ the presence of lace as a fashion ornament is well-documented in the Dalmatian region. The value of lace was equal to that of gold and, in London, in 1787, it exceeded it tenfold. ${ }^{21}$ A comparable gold-lace value ratio was also recorded in Dalmatia. Therefore, lace had become an essential part of the dota, a woman's dowry brought into the marriage, but under the husband's control thereafter. This custom enabled a maiden to acquire a proportion of her parents' property, as the remainder would be shared amongst her brothers on their parents' death. Girls would start making their dota (dowry) at the age of ten, since they were married in early adolescence. As everything was handmade, from the stitchery and hand embroidery to the lace and finished garments, the making of the dowry was a very lengthy process. More affluent young females attended schools that allowed for this by including periods of monastic seclusion, whereas their peers from more modest backgrounds were educated by their elders. ${ }^{22}$ Dowries typically included shirts with lace cuffs; as traditional jackets of the period had slightly shortened sleeves, the cuffs would be prominently displayed. ${ }^{23}$ These trimmings were made from a multilayer lace called cascada or postica, ${ }^{24}$ commonly used to decorate both men's and women's garments.

With the arrival of the Benedictines, ${ }^{25}$ who transferred their knowledge and skills to the indigenous population, ${ }^{26}$ the practice of lacemaking spread in Dalmatia, particularly on the island of Hvar. The intensive production of highquality lace dates back to the 16th century, and was connected primarily to the territories of Dubrovnik, Boka Kotorska, and the Dalmatian islands. ${ }^{27}$ Female

20 Marijana Gušić, "Uz pitanje dubrovačke čipke" [Questions About the History of Dubrovnik Lace], Anali Historijskog instituta u Dubrovniku [Annals of the History Institute in Dubrovnik] (Dubrovnik:1952), 331-340.; Nevenka Božanić-Bezić, "Prilog dubrovačkom umjetničkom vezivu XVI. stoljeća" [The Contribution of Dubrovnik Embroidery from the 16th Century], Prilozi povijest umjetnosti u Dalmaciji [Annals of the History Institute in Dubrovnik], 14 (Split:1962), 56-164.

21 Alessandra Mottola Molfino and Maria Teresa Binaghi Olivari, I pizzi: moda e simbolo (Milano: 1977), 29.

22 Nevenka Božanić-Bezić, "Čipka na odjeći", 9-17.

23 AIS-II, III, State Archives Split, I Archive Kapogrosso-Kavanjin. Split City Museum; Nevenka Božanić-Bezić “Čipka na odjeći”, 10.

24 Nevenka Božanić-Bezić, "Čipka na odjeći”, 12.

25 Benedictines arrive on the island of Hvar in 1664. Grgo Novak, Hvar kroz stoljeća, [The Island of Hvar Through the Centuries] (Hvar :1972), 130-133.

26 Marijana Gušić, "Proučavanje čipkarske proizvodnje na Hvaru”, [The Study of Lace Production on Hvar] Ljetopis JAZU [Annals JAZu], Vol. 67, (Zagreb: 1960), 326-238.

27 Marijana Gušić, "Uz pitanje dubrovačke čipke” [Questions about the History of Dubrovnik Lace], Anali Historijskog instituta u Dubrovniku, (Dubrovnik: 1952), 331-340. 
convents were sites of intensive manufacture of expensive lace intended for foreign markets and local nobility. ${ }^{28}$ Archival records document extensive lace production in Dalmatia throughout the 17 th and 18 th centuries, which was sold in larger European capitals as Venetian lace, ${ }^{29}$ thus greatly compromising the attempts to trace the use of Dalmatian lace in the clothing of other European capitals.

Lacemaking was predominantly the activity of nuns and tertiaries, the socalled picokare; members of the Third Order who were loyal to a particular convent. ${ }^{30}$ Picokare were women who had not taken solemn vows but were nevertheless sworn to purity and absolute loyalty to their faith. ${ }^{31}$ They would run errands for the mainly secluded monastic orders. Domestic manufacturers also produced lace, which tended to imitate the technique and style of the lace made in convents and which would later be applied to a variety of garments. Archival records show that women from the islands of Hvar and Vis, ${ }^{32}$ as well as women from Dubrovnik, ${ }^{33}$ Kotor (Fig. 3.2) and the surrounding areas were particularly skilled at lacemaking and embroidery. Since lace was frequently mentioned in the inventories of deceased noblemen and commoners, we can assume that it was not imported in large quantities as it was extremely expensive in European capitals at that time; rather, it was made locally by women and maidens. However, the inventories of Dubrovnik merchants note the importation of expensive Flemish lace, which was sold along the entire Adriatic coast. ${ }^{34}$ During his stay in Dalmatia in 1774 , Alberto Fortis documented the popularity of lace trimmings among commoners in the Zadar region ${ }^{35}$

28 Church collections, i.e. lace artefacts preserved in Kotar-Dobrota, Hvar and Zadar, presently give evidence of the delicacy of lace ornaments available in Dalmatian markets from the 16th to the 19th century.

29 Nevenka Božanić-Bezić, "Prilog istraživanju čipke", 60-72.

30 Marijana Gušić, "Zbirka čipaka sv. Marije u Zadru” [Laces from the Church Museum of Saint Marija in Zadar], Radovi Zavoda JAZU [Articles of Department JAZU], vI-VII (Zadar: 1960), 81-96.

Nevenka Božanić-Bezić, Tragom renesansno-barokne čipke u dalmatinskim samostanima, [Renaissance and Baroque Lace in Dalmatian Monasteries] (Korčula: 1999), 109-117.

32 Nevenka Božanić-Bezić, "Tradicija čipkarske tehnike na otocima Hvaru i Visu od XVII stoljeća do danas" [Traditions of Lacemaking on the Islands of Hvar and Vis from the 17th century Onwards], Makedonski folklore [Macedonian folklor], XVIII, 35 (Skopje: 1985), 101-106.

33 Nevenka Božanić-Bezić, "Prilog dubrovačkom umjetničkom vezivu XVI. Stoljeća” [The Contribution of Dubrovnik Embroidery from the 16th Century], Prilozi povijest umjetnosti u Dalmaciji [Contributions to the History of Art in Dalmatia], 14 (Split:1962), 153-164.

Alberto Fortis, Put po Dalmaciji [Travels into Dalmatia], (Split:2004), 8, 17. 


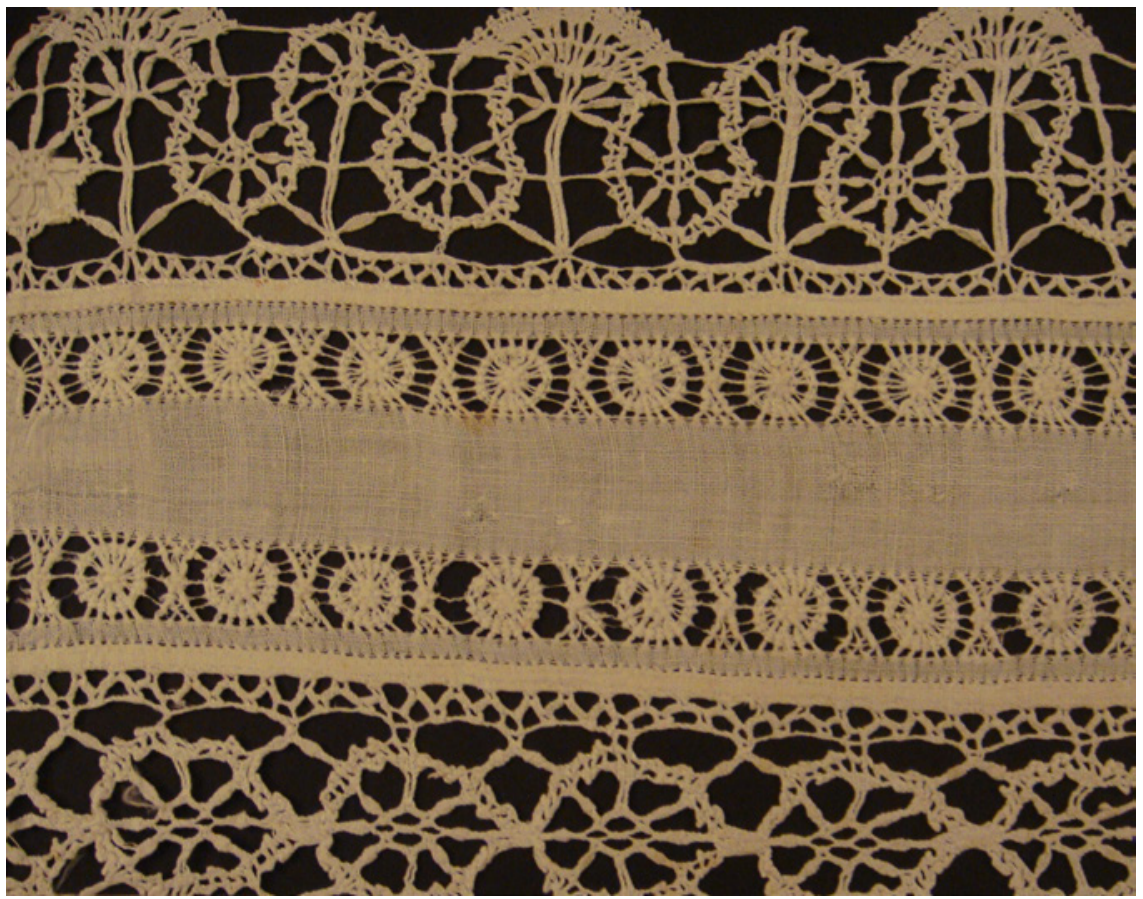

FIGURE 3.2 Lace, Collection from Dobrota, Kotor.

(Fig. 3.3). The significance of this documentation for the history of Dalmatia is also emphasized by Giulia Calvi in her chapter.

In 18th-century Dalmatian inventories, lace is frequently mentioned as an ornament on aprons, men's suits, women's dresses, armholes and necklines. ${ }^{36}$ It was mainly made using needle, bobbin, and knotting techniques. It was a favourite pastime of local women along the Dalmatian coast and bobbin lace pillows were therefore often mentioned in dowries. ${ }^{37}$

Women of the upper social classes applied decorative lace, most commonly made from gold and silver threads, to the fronts and backs of their jackets. Jackets worn by members of the nobility had armholes ornamented in multilayer lace, while middle-class women mainly wore simple shirts with singlelayer lace sewn around the armholes and neckline. Lace was also the primary

${ }_{3} 6$ Nevenka Božanić-Bezić, "Hvarske i viške u svjetlu arhivskih izvora od 16. do 18 stoljeća", [Archival Records from Hvar and Vis from the 16th-18th Centuries], Prilozi povijesti otoka Hvara [Contributions to the History of the Island of Hvar], x (Hvar: 1997) 101-109. Ibid., 102. 


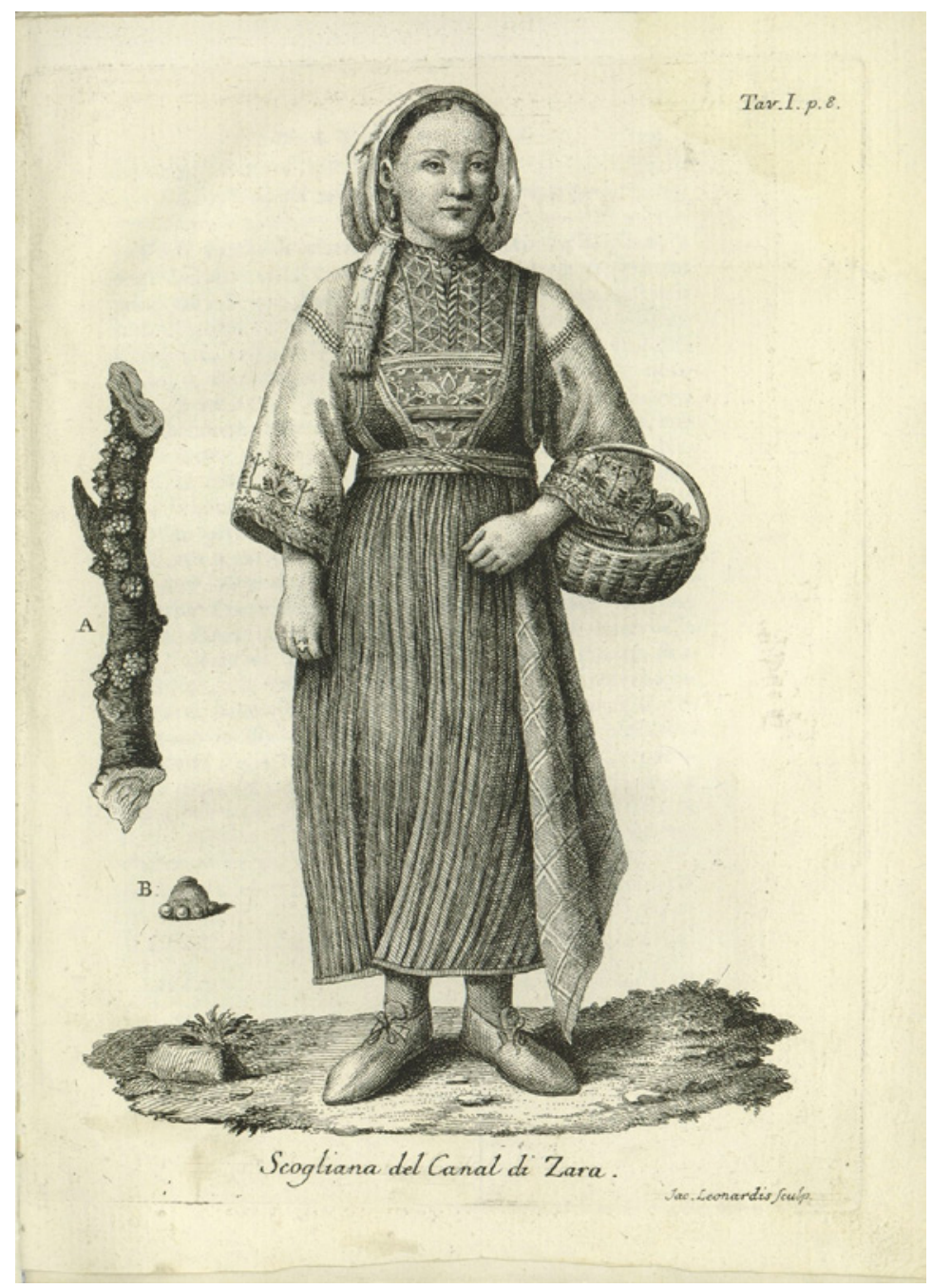

FIGURE 3.3 Alberto Fortis: Young women from Zadar, 18th century (Alberto Fortis, Put po Dalmaciji [Travels into Dalmatia], (Split: 2004,17.), Zbirka rukopisa i starih knjiga Ns K; Gajeva knjižnica; Europa čita = Reading Europe: European culture through the book, NSK ooo692410.

decoration on shoulder covers, headgear, and neck scarves given to maidens by their fiancés as gifts. Silk or damask aprons lavishly decorated with lace and worn as accessories to the dress were particularly popular among Dalmatian middle-class women. Ornamental lace frequently covered the cleavage, providing a soft transition from a woman's gentle skin to the garment. 


\section{Clothing and Textile Artefacts from 18th-Century Dalmatia}

As mentioned before, intensive trading allowed affluent Dalmatian ladies of the 18th century to choose from two basic types of garment: the so-called closed type of dress (robe volante, robe battante, mantua - the main feature of the robe volante being a wide drape falling from the shoulder down the back) and the so-called open type of dress with the front opening revealing the petticoat underneath, also referred to as robe à la française (contuche or sack-back gown). The armholes were decorated with multilayer lace called engageantes, cascada, or postica. ${ }^{38}$ Several preserved portraits from the Dalmatian region illustrate this type of dress. However, influences from England were starting to play a more prominent role in setting out European fashion guidelines, with the Duchess of Devonshire serving as a paragon of the English style. Features such as cut constructions, typical of English menswear, and unadorned fabrics, free from metallic or gold silk embroidery, laid the foundations for a purer, simpler, and smoother Neoclassical style in comparison to the sumptuous and dynamic French Rococo fashions. Long, straight sleeves and tight-fitting coats created a refined, elegant silhouette. This new climate brought about the popularity of the robe a l'anglaise (English dress) in the 1770 , although it had been present on the fashion stage since the mid-18th century. In Dalmatia, in 1784, a dress called an inglesina is listed as a dowry asset of Ruža Majstrović from Makarska, engaged to captain Franjo: "The skirt and the inglesina were made of the same fabric, wool (sukno), in a red, green and light-blue colour."39 A notary record reveals that inglesina was also a term denoting an outer dress in Dalmatia. At the end of the 18th century, a jacket referred to as an inglesina is often mentioned in historical dowry records. ${ }^{40}$ Dresses in French (mantua), English (inglesina), and Italian styles (vestura, vesta, carpetta, mezzo manto, zipponzin, tabaro, sotana, polachette, busto, cottole, sotto abito ${ }^{41}$ ), along with garments of Turkish origin (mahrame ${ }^{42}$ ) were commonly owned by the nobility and middle-class women. The greatest difference between such garments was in the price of the fabric. According to archival records, female members of the lower social

38 Božanić-Bezić, "Čipka na odjeći”, 11.

39 Božanić-Bezić, Juditini dvori [Judith's Chambers], 80.

40 English maiolica dishes were especially valued in 18th-century Dalmatia.

41 Vestura-dress; vesta—skirt; carpetta-a short-sleeved dress, skirt, jacket, or carpet in Dubrovnik; mezzo manto, zipponzin — garments similar to a jacket or waistcoat; tabarocape; sotana -dress; polachette — jacket with buttons; busto—waistcoat; cottole —dress, sotto abito-undergarment.

Mahrame-scarf. See Božanić-Bezić, Juditini dvori, 66. 
classes wore simple dresses made of cheaper fabrics, most often from wool or linen yarn in plain weave. ${ }^{43}$ Unfortunately, there are no records of any remaining garments or textile artefacts from the lower social classes.

It is interesting to note that most surviving clothing artefacts from 18thcentury Croatia are, in fact, menswear. ${ }^{44}$ Preserved high-quality samples of women's fashion from the 18th century are very scarce and the three garments still in existence, two jackets and a skirt, all belonged to members of the higher social classes in Dalmatia at that time.

The two women's jackets in blue and red silk, ${ }^{45}$ decorated with gold and silver bobbin lace on the back, belonged to the Kasandrić family from the island of Hvar. The red damask silk jacket is preserved in the Split City Museum (Fig. 3.4), while the navy-blue damask jacket is kept at the Museum of Arts and Crafts in Zagreb. ${ }^{46}$ Both jackets have a trapeze neckline and long sleeves. The gold and silver lace on these jackets was applied in the form of an ornamental ribbon that follows the seams between garment sections, embellishing the neckline, the back cut and the lower edge of the jacket. According to archival records, both items were purchased in Venice, thus indicating the important role of strong Italian fashion influences.

43 Fani Celio Cega, Svakidašnji život grada Trogira od sredina 18. do sredine 19. stoljeća [The Daily Life of Trogir from the Mid-18th to Mid-19th century], (Split: 2005).

44 Parts of a man's suit from the second half of the 18th century are preserved at the Museum of Arts and Crafts in Zagreb, the Rector's Palace in Dubrovnik, Šibenik City Museum, Split City Museum and the Historical Museum in Zadar. According to available information, the only entirely preserved attire comprises of all three elements of Gozze's ceremonial suit, which is kept on permanent display at the Rector's Palace in Dubrovnik. This collection also contains a waistcoat with illustrated buttons and Nikša Pozza's day suit, minus the waistcoat. Šibenik City Museum houses a green frock coat, a white waistcoat with metallic embroidery, and a short white embroidered waistcoat owned by the noble family De Dominis Gogala from Šibenik. All these garments have several common features: they were all made from fabrics woven, cut, sewn and embroidered in French workshops, but it cannot be precisely determined whether in Paris or Lyon. It should be noted that Croatian noblemen and affluent citizens were, unlike ladies, often portrayed wearing coats and jackets resembling military uniforms, or coats in an oriental style.

45 Vanda Pavelić, Oblici odjeće [Types of Clothing] (Zagreb: 1955); Božanić-Bezić, "Čipka na odjeći", 11.

46 Katarina Nina Simončič, "Jacket-bodices from the End of the 17th Century—Analyses and Attributes", Book of Proceedings for the Seventh International Textile, Clothing \& Design Conference (Zagreb: 2014), 640-645. 


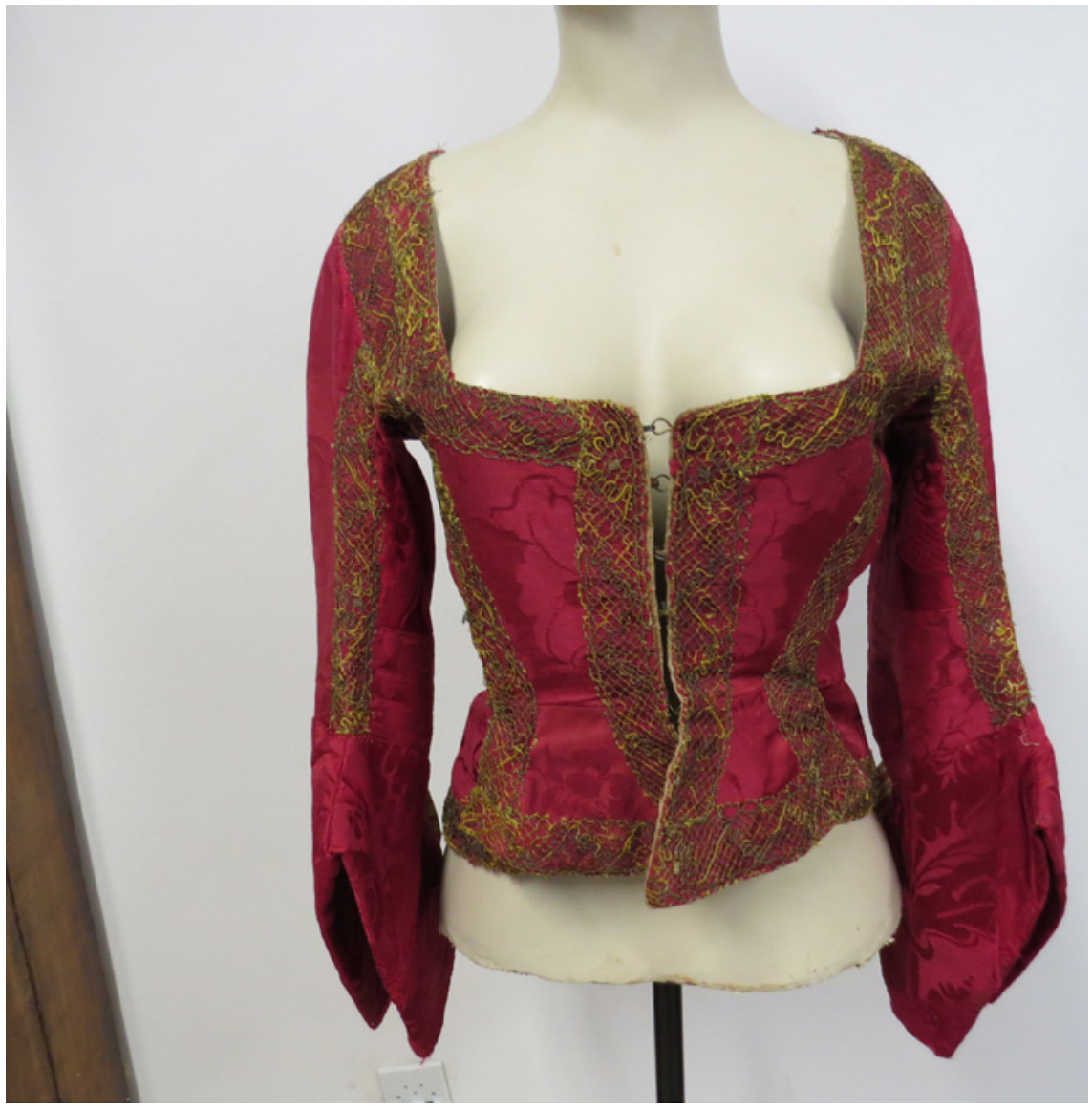

FIGURE 3.4 Jacket-bodice of red silk, 1770s, Museum of town Split, Split, Croatia (inventory number $M G s-837$ ).

The Museum of Arts and Crafts in Zagreb also houses a skirt ${ }^{47}$ made from silk fabric in gold and yellow with bizarre motifs (Fig. 3.5). Fabrics with bizarre motifs were very popular in late 17th- and early 18 th-century Europe, especially in Italy, England, and France. Cora Ginsburg describes this group of designs as Asian-inspired Baroque ornaments that were sometimes woven in the East to suit the demands of the lucrative European export market. ${ }^{48}$ According to

47 The skirt is comprised of seven silk panels. Its overall width is 3.5 metres and the length is 1 metre.

48 Cora Ginsburg, Chinese Export for the European Market, ca. 1708-10. Source online: http:// coraginsburg.com/catalogues/2009/cat2009pg4-5.htm (27.01.2017.). 


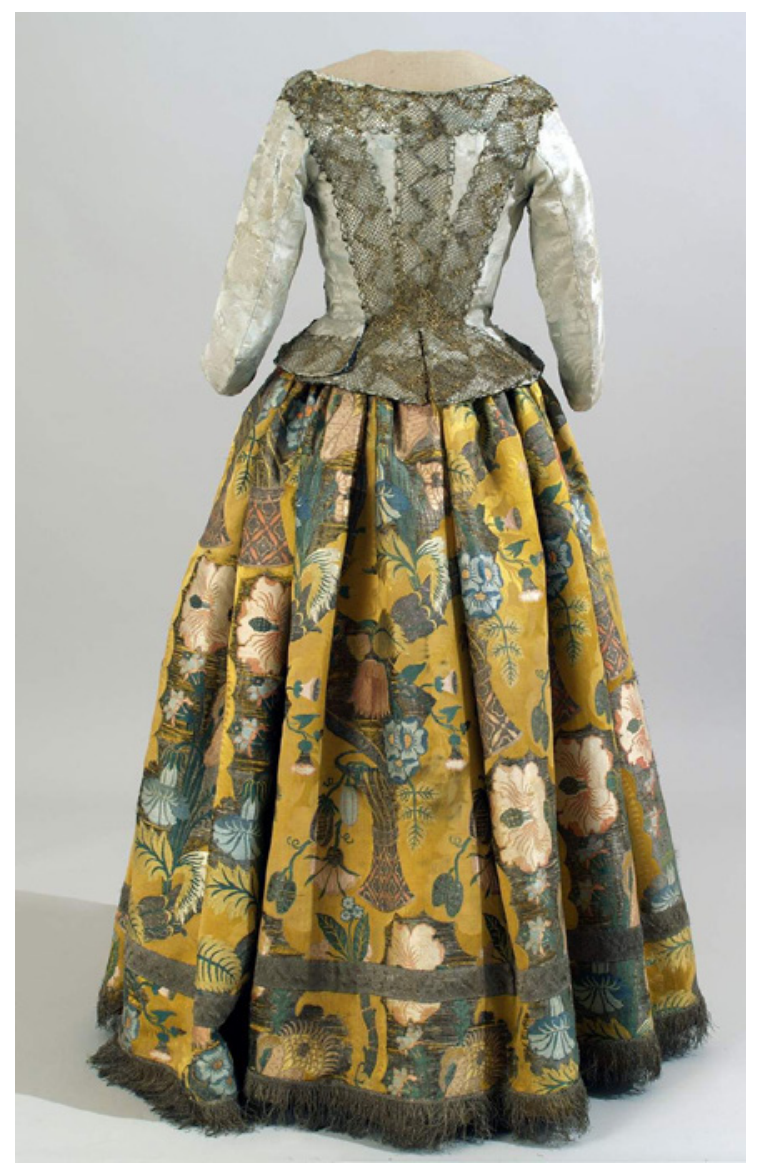

FIGURE 3.5

Jacket-bodice and skirt, 18th century, Museum of Arts and Crafts in Zagreb, Croatia (inventory number 10250 of jacket-bodice and skirtMUO 6013).

Ackermann, the term bizarre fabric was first used by Ernst Scheyer in his doctoral dissertation on Chinoiseries, in 1928, though without proper definition. Ackermann also asserted that bizarre fabrics were woven for a relatively short period of time, between the very end of the $17^{\text {th }}$ and the first twenty years of the 18 th century. They were produced mostly in Europe for wealthy clients. ${ }^{49}$ The skirt from Zagreb was found on the border of the Venetian Republic and the Independent Republic of Dubrovnik. It had belonged to the Lamuelli-Kačić

49 Ackermann also points out that the term bizarre fabrics means a specific style of pattern, not a specific weave. 'Bizarre' style was described as a flowery décor filled with abstract elements. A dynamic composition gives the full bizarre effect. Hans Christoph Ackermann, Seidengewebe des 18. Jahrhunderts I. Bizarre Seiden (Abegg-Stiftung 2000), 41-75 and 264-390. 
family from Blato on the island of Korčula. On the brocaded yellow satin background, we can observe branches, leaves, flowers and vases in pink, green, and blue. Among them, meandering decorative motifs are shaped using metallic thread. French artisans in Lyon workshops probably manufactured the textile at the beginning of the 18 th century. ${ }^{50}$

However, a special category, which should be acknowledged in the attempt to comprehend the value of textiles as an indicator of social status, is comprised of liturgical artefacts. These can be observed in church collections in the territories of Kotor, Dubrovnik, Zadar, Lopud, Rab, Hvar, Šibenik, Skradin and Split. Liturgical garments were made from silk fabrics manufactured in Venetian and French workshops. Some of these fabrics, which were not primarily intended for liturgical but rather secular purposes, can be observed as a secondary source of fashion fabrics owned by affluent Dalmatian women in the 18th century. Luxurious silk fabrics, an indisputable status symbol, were not reserved solely for liturgical vestments but were also used to clothe wooden statues of the Madonna. Several samples of these bizarre fabrics are preserved on the island of Rab. ${ }^{51}$

\section{Dalmatian Portraits from the 18th Century—-Sources of Fashion Insight}

Apart from Alberto Fortis's depictions of commoners, portraits also allow an interesting insight into the culture of living in that period. Unlike clothing artefacts, the number of preserved 18th-century portraits in Croatian museums is relatively high. These portraits give insight into the presence of various fashion styles and patterns in the Dalmatian region, provided we analyze them simultaneously with archival records (testaments, notary and trade records). In this context, we will consider the portraits of two Dalmatian noblewomen: Katarina Righi Budmani (1765-?) and Ana Ghetaldi Sarako (1761-1819) from Dubrovnik. Further on, we will focus on the picture of a middle-class woman from Makarska. This visual source of women from Makarska was preserved thanks to Fortis's ${ }^{52}$ travels through Dalmatia, and shows how oriental style and French fashion was adopted and assimilated into Dalmatian fashion styles.

5o Jelena Ivoš, "Liturgijsko ruho" [Liturgical Vestments], Zbirka Tekstila Muzeja za Umjetnost i obrt (Zagreb: 2010), 31.

51 Banić, "Prilog poznavanju", 461-499.

$5^{2}$ Alberto Fortis (1741-1803) was a Venetian writer, naturalist, and cartographer. He journeyed extensively in Venetian Dalmatia. His best-known work is Viaggio in Dalmazia (Travels into Dalmatia), originally published in 1774 and first published in London in 1778. 
The portraits "Katarina Righi Budmani" (Fig. 3.6) and "Ana Ghetaldi Sarako" (Fig. 3.7) from Dubrovnik illustrate two different fashion styles at the end of the 18th century with regards to hair, make-up, ornamentation and, in part, garments. A strong French influence is evident in both cases, which provided

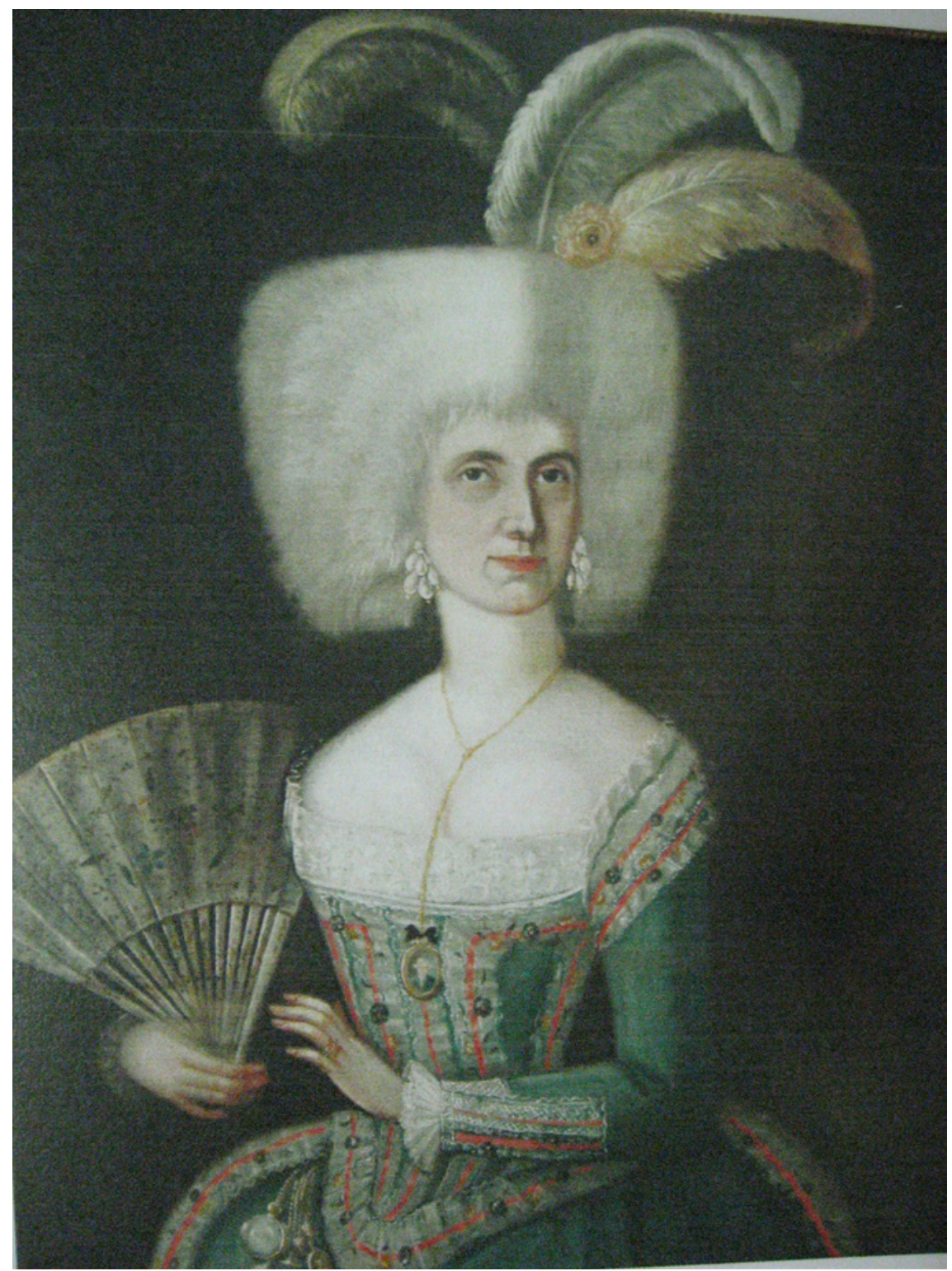

FIGURE 3.6 Portrait of Katarina Righi Budmani, from the end of 18 th century, Rector's Palace in Dubrovnik, Croatia (inventory number: DUM KPM SL-295). 


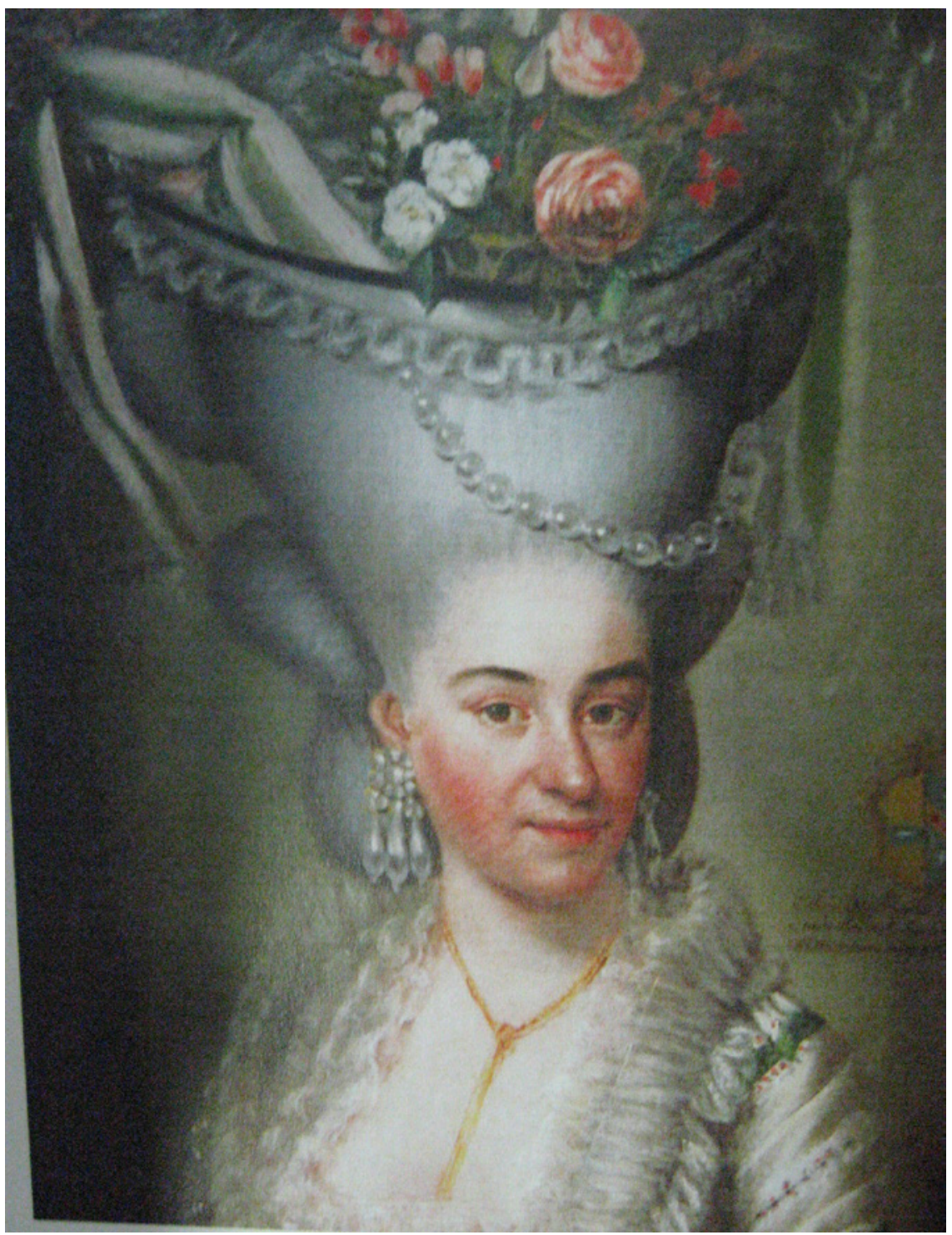

FIGURE 3.7 Petar Katušić: Portrait of Ane Ghetaldi Saraca (Saraka), around 1781, Rector's Palace in Dubrovnik, Croatia (inventory number DUM KPM SL-188).

remarkably creative adaptations in fashion styles in the wake of social revolutions and the reconstruction of class society at that time.

The portrait of Katarina Righi Budmani, by an unknown author, is preserved in the Rector's Palace in Dubrovnik and dates from the end of the 18th century. Due to the accentuated and sharply curved hips, the first impression of the 
dress suggests the form of a robe à la française. During the 1770s, this dress was worn primarily for formal ceremonies, whereas the robe a l'anglaise and robe à la polonaise were more commonly worn during the day. However, if we take the artist's technical skills into account and observe the difficulties in the realization of perspective, especially in the area around the shoulders, it is evident that determining the form of the garment should be approached with care. Another cause for caution is the fact that the lower part of the portrait ends at the hips, which makes it impossible to establish the direction of the decorative contours, the length of the dress, and, ultimately, the precise type of dress. Very narrow and simple sleeves, without elaborate decorations, indicate the common form of sleeve worn in the late 1770 and early 1780 .

However, if we compare this dress to a robe à la polonaise ${ }^{53}$ model from 1774/93 exhibited in the Metropolitan Museum of Art, we can observe similarities both in form and trimmings. Similar elements can also be observed on the model of a robe à la française, ${ }^{54}$ an artefact dating from 1780 , exhibited in the same museum. The highly reduced waist, stomacher with silk ribbon decorations (the term pettorine or prsnica ${ }^{55}$ was also used in Dalmatia), lace, ornamental buttons and accentuated, somewhat sharp hips, which seem to be shaped like a pannier, all indicate that the dress in question is of a robe à la française type.

Katarina Righi Budmani's jewellery includes earrings, a necklace, a ring and a piece of functional jewellery worn around the waist, the so-called chatelaines or equipage (gear). This type of jewellery, worn throughout the 18th and 19th centuries due to its practical and decorative qualities, was usually made of gold, silver, steel or other metals from which multiple pendants hung: a scissors etui, a watch, a puff box, smelling salts, keys, wax boxes, a thimble etc. The pendants observed in the portrait include a portrait medallion, several bells, and a pocket watch. A golden equipage, silver charms resembling blades, a golden heart-shaped charm, filigree crosses, pearls, gemstones and medallions with images of the Madonna, St. Anthony, and St. Helen are often mentioned in wills and dowries across Dalmatia. ${ }^{56}$

\footnotetext{
53 Accession Number: 34.112a, b.

54 Accession Number: 2009.300.855.

55 Božanić-Bezić Juditini dvori [Judith's Chambers], 210.

56 Božanić-Bezić, Juditini dvori [Judith's Chambers], 8o; Vedrana Gjukić-Bender, Zbirka portreta iz fundusa Kneževa dvora-muzejsko prezentacija, podrijetlo, putovi nabave [A Collection of Portraits from the Funds of the Rector's Palace in Dubrovnik] (Doktorska disertacija obranjena na Filozofskom fakultetu) (Sveučilište u Zagrebu: 2012). (Doctoral dissertation held at the Faculty of Humanities and Social Sciences, University of Zagreb: 2012).
} 
The pearl earrings in the portrait drop in two lines of three tear-shaped forms. This formation of three clusters was common in mid-18th century fashion under the term girandole earrings. ${ }^{57}$ Diamond girandoles can also be observed in the portrait of the Austrian princess Maria Luisa of Parma (1765) and Maria Luisa, the Grand Duchess of Tuscany by Anton Raphael Mengs (1764-5), as well as in the portrait of Ana Ghetaldi Sarako from 1781. Gold, silver, diamond, coral, pearl and filigree earrings were frequently given as gifts among the members of the privileged social classes in Dalmatia. ${ }^{58}$ The gold necklaces observed in both portraits from Dubrovnik are of the same style and manner of wearing; however, Katarina Righi is wearing a necklace with a portrait medallion, a piece of sentimental or memento mori jewellery, which was especially popular in the second half of the 17th century.

In the 1770s, hairstyles in the French court reached the peak of inventiveness and creativity. The portraits from Dubrovnik feature two types of hairstyles, both with distinctive French signatures, even though there is no record of them in written sources. These portraits therefore represent the most valuable source of information available to comprehend the functioning of status symbols among the privileged classes in Dalmatia. In order to attain the desired height of the crown portion, women used implants made of wool, hemp fibres, and hair remnants or would even insert wire frames to build an entire composition around it. These elaborate hairstyles were additionally decorated with bands, pearls, flowers, vegetables, or even small replicas of ships and birdcages. In 1774 , the Duchess of Devonshire created a great sensation by decorating her hair with an ostrich feather, as did Katarina Righi Budmani in the portrait from Dubrovnik. However, the latter depicts a somewhat more prominent crown portion of the hair resembling a bulge, with slightly geometrical forms of backcombed hair, which is typical of the French style at the end of the $1770 .^{59}$

The portrait of Ana Ghetaldi shows a white-coloured dress. A white dress, often mentioned in merchant lists from the Dalmatian region, was a more frequently encountered fashion garment from 1775 onwards, with the dominance of specific white hues: the so-called cheveux de la Reine (French for queen's hair-a burnished-blond hue similar to the colour of Marie Antoinette's hair) and couleur de puce (French for a deep red to dark greyish-purple), a colour Louis XVI of France was particularly fond of. Silk dyers of the 18th century used one basic dye to develop up to 30 different hues. For example, for white, there were six basic colours with multiple hues, with the following names: Indian

59 Aileen Ribeiro, Facing Beauty: Painted Women \& Cosmetic Art (New Haven: 2011). 
white, Chinese white, raw yarn white, milk white, blue white and silver white. The difference in colouration of these fabrics was minimal and visually perceptible only when the fabrics were laid out close next to one another. ${ }^{60}$

The portrait of the woman from Makarska by Alberto Fortis provides insight into the clothing culture of middle-class women in the 18th century. It also explains the influences that shaped the Dalmatian fashion style as it has since been preserved in traditional culture. In our reconstruction of fashion styles of this period, we observe with interest the assimilation of oriental style elements, adopted from the French court, with elements of indigenous clothes. In the intensive trade of the mid-18th century, the West was shipping French and Italian silk and English wool to the East via Venice, Ancona, Split or Dubrovnik, while eastern fabrics and Turkish oriental garments were imported to Venice via Split. Unlike western fashion garments of this period, oriental clothes did not restrain the human body but tended to reveal and affirm it. ${ }^{61}$ Perhaps, it was precisely on these trade routes that dresses such as the robe turque or robe à la Sultane travelled to the French court. ${ }^{62}$ Madame de Pompadour posed as a sultana for the artist Charles-André van Loo for her portraits in 1747 and 1755. The infatuation with oriental garments did not bypass the Viennese court, where Martin van Meytens portrayed Queen Maria Theresa in that style of dress (1744/1745). These garments also arrived in Dalmatia, where the robe turque was often worn by rich young women in Makarska (Fig. 3.8). ${ }^{63}$ They belonged to the affluent social class of merchants and mariners, which emerged in the aftermath of the Ottoman-Venetian wars. This social class replaced the impoverished local nobility on the social ladder. Their daughters' dowries were often more abundant and luxurious than those of the impoverished local nobility. ${ }^{64}$ As opposed to their peers in other cities, young women from Makarska wore

6o Melissa Hyde, “The 'Makeup' of the Marquise: Boucher's Portrait of Pompadour at Her Toilette", The Art Bulletin, 82, 3 (London: 2000), 453-475.

61 Bajić-Žarko, Split, 89.

62 Parisian and London coloured fashion illustrations from the beginning of 1770 show the creative expansion of forms and terminology in women's fashion. This period marks the emergence of styles such as à la circassienne, à la levantine, à la crèole, which liberate the body like the aforementioned dress of the $\grave{a}$ la sultana type, remaining in vogue since the reign of Madame de Pompadour. Jane Ashelford, The Art of Dress. Clothes through History 1500-1914 (London: 1996), 140-141; Madeleine Delpierre, Dress in France in the Eighteenth Century (New Haven: 1997), 68.

63 The drawing in Alberto Fortis's travelogue depicts a female commoner from Makarska, later used by Ivan Lovric in his work. Ivan Lovrić, Bilješke o putu po Dalmaciji opata Alberta Fortisa [Notes on Travels in Dalmatia], tabla v (Zagreb: 1948).

64 Božanić-Bezić, "Čipka na odjeći”, 13, 76. 


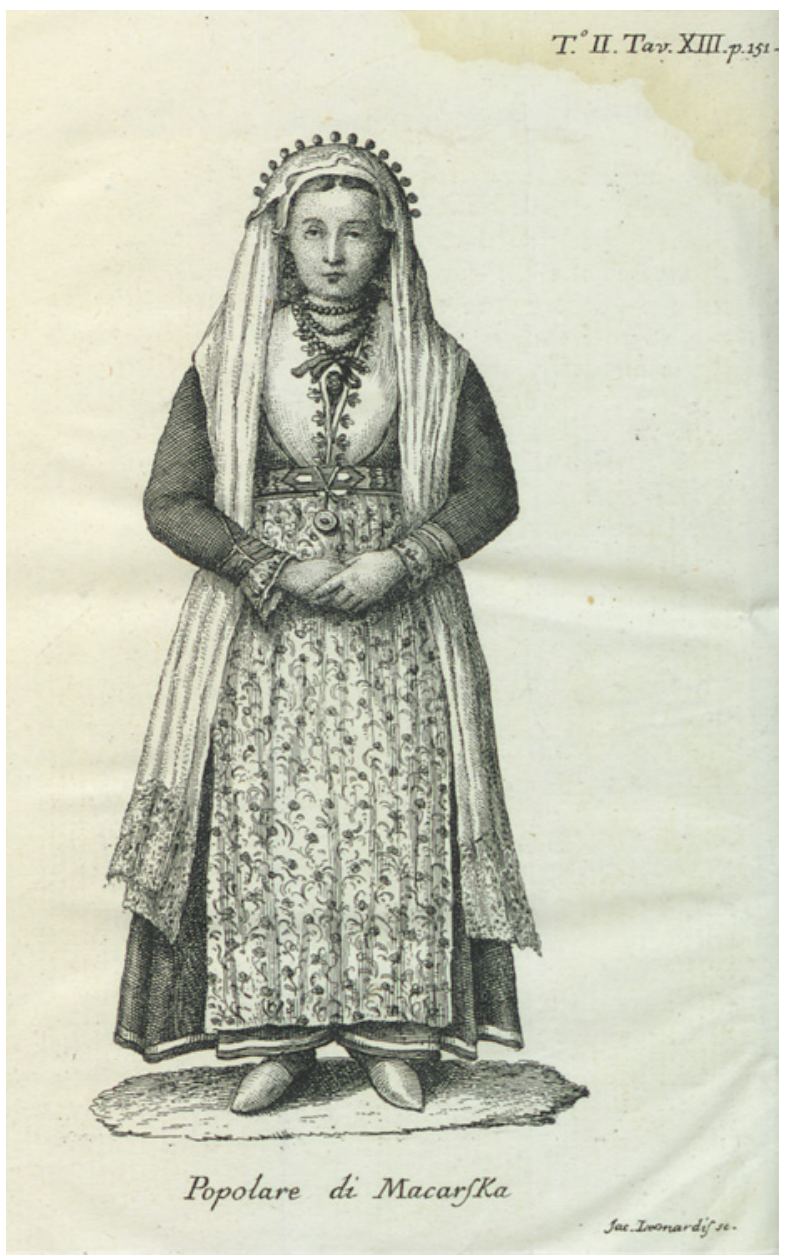

FIGURE 3.8 Alberto Fortis: Young women from Makarska, 18th century Ivan Lovrić, Bilješke o putu po Dalmaciji opata Alberta Fortisa [Notes on 'Travels in Dalmatia], tabla V(Zagreb: 1948), Zbirka rukopisa i starih knjiga NsK; Gajeva knjižnica; Europa čita = Reading Europe: European culture through the book, NSK ooo692410.

a variety of headscarves such as the alla turchescha or alla turca, ${ }^{65}$ along with the headgear turban, a jacket called a jelek—geleco, ${ }^{66}$ made from fine Turkish

65 Božanić Bezić, Juditini dvori [Judith's Chambers], 62.

66 Ibid., 68. 
silk, and other heavily-fringed items. Affluent mariners ${ }^{67}$ brought Turkish silk scarves (mahramas), while women sewed their own jackets out of fine silk fabrics from Levant, wore shoes from Genoa and Livorno, and golden shoes from Constantinople, ${ }^{68}$ as noted in the archives and the following folk poem:

\author{
And I will pray to the God Almighty, \\ To blow the winds from down below, \\ To bring the ship "Saruh" back to Pelješac, \\ With my darling on board back from Levant \\ Bringing me white scarves, \\ Silk, gold and other treasures \\ And the beautiful Levant thread, \\ For me to make beautiful attires \\ To walk gaudily all the way \\ Even in my old age ${ }^{69}$
}

67 Dalmatian mariners arrived in the ports of present day Belgium and the Netherlands, where they acquired Dutch and Reims plain weave fabrics used to sew women's shirts. These fabrics were owned by every middle-class bride. Young women of lower social classes attempted to sew at least sleeves out of this fabric. Nevenka Božanić-Bezić, "Odijevanja u Hvaru u XVIIII stoljeću” [Dressing on the Island of Hvar in the 18th Century], Juditini dvori [Judith's Chambers], (Split: 2001), 187-203.

The family Fisković in Orebić still preserves an Indian 18th-century fabric, brought by the captain Jozo Fisković from Mauricius, which was an intermediary trading point with India in that period. Cvito Fisković, "Putovanje na pelješkom jedrenjaku s kraja 18. i početka 19. stoljeća" [The Journey of Pelješac Sailing Boats from the Late 18th to Early 19th Centuries], Pomorski zbornik [Maritime Almanac], (Zagreb: 1962), $175^{2}$.

68 Božanić-Bezić, Nevenka, "Utjecaj pomorskih veza na kulturu življenja u Dalmaciji i Dubrovačkoj Republici od 15. do 19. stoljeća” [The Influence of Maritime Connections on the Culture of Life in Dalmatia and the Dubrovnik Republic in the 15th and 19th Centuries], 66 .

69 I molit ću Boga velikoga,

Da zapuha odazdala vitra, da brod "Saruh" doje do Pelješca, i s njim da doje dragi s Levanta.

I donese bilih ubrusaca, svile, zlata, blago diferanta.

I lipoga konca od Levanta,

Sa čim hoću lipu robu šiti. do starosti gizdava hoditi.

Cvito Fisković, "Orebička ženska narodna nošnja" [The Female Folk Costume from Orebic], Pelješki zbornik I [Peljesac Almanac], (Split: 1976), 227-268. 
Young women from rich mariners' families adopted the Turkish dress code as it gained popularity in the French court to communicate their newly gained financial power.

Moreover, lower social classes quickly adopted eastern garments (as well as the terminology), which were cheaper than western fashion merchandise. As the importation of goods was probably compromised following the outbreak of the Turkish-Venetian war, domestic craftsmen started making Turkish artefacts of their own. ${ }^{70}$ It should be noted that the alla turca style, which was considered fashionable in 18th-century Dalmatia, became a part of the traditional culture over time. A preserved photograph of a woman from Makarska from $1905,{ }^{71}$ which is currently housed in the Berlin Archive, and traditional folk costumes which still manifest the cultural identity of this region substantiate this claim.

Unlike French fashion, the Turkish style did not strive to constrain the female body in corsets or panniers, but to hide it from the public eye. Strong Turkish influence in Dalmatia can be observed until the end of the 18th century, when middle-class women started abandoning the custom of covering their heads, as described in a humorous folk poem from the period:

Some women and girls

Having seen their daughters and old mothers

Revealed their hair, and their breasts.

And they feel no shame

Sitting in the church.

With a proud cheek and their bosom on display. ${ }^{72}$

70 Božanić-Bezić, Nevenka, "Utjecaj pomorskih veza na kulturu življenja u Dalmaciji i Dubrovačkoj Republici od 15. do 19. stoljeća” [The Influence of Maritime Connections on the Culture of Life in Dalmatia and the Dubrovnik Republic in the $15^{\text {th }}$ and 19th Centuries], Juditini dvori [Judith's Chambers], (Split: 2001), 62.

71 Staatliche Museen zu Berlin, Nr.: N (74 P) 62/2007, 32d.

$72 \quad$ Neke žene i divojke.

Videć ćeri, stare majke.

Odkriv kose, još I dojke.

I mnoge se sad ne stide.

Neg u crkvi one side.

Obraz prsi nek jim vide.

Ivan Milčetić, "Duhovne i šaljive pjesme iz Makarske" [Spiritual and funny poems from Makarska], Građa za povijest književnosti $V$ [Archives for Literature History], (Zagreb: 1907), 163 . 
Owing to the work of Alberto Fortis, we learn more about the dressing habits of the lower social classes. Their clothes were primarily functional and seldom subject to change; they were commonly made from rough woven fabric ( $r a s ̌ a)$ and exhibited strong features of Turkish style. ${ }^{73}$

In our review of women's dress code in 18th-century Dalmatia, it is essential to gain an understanding of women's position in their families and society as a whole. Their position was slightly more favourable in Dalmatian coastal towns and on the islands, in comparison to women living in rural communities of the Dalmatian hinterland. Women of all social classes could ensure or enhance their social status by "marrying well". Potential brides used their clothes as a form of non-verbal communication, i.e. their garments were an indicator of their financial status. Whether traditional or fashionable, clothing was an indicator of luxury. The level of fashion consciousness depended on social class, and was exhibited through the choice of luxurious fabrics, garments arriving from both western and eastern markets, embellished by embroidery in intensive colours (especially red), lace trimmings, and jewellery. The dowries of noble and more affluent middle-class women comprised fashion articles from the West, combined with oriental garments. Women from more modest backgrounds sewed and embellished their own garments. However, the uncertain future of Dalmatian lower-class women encouraged them to pursue careers in the fashion market during the 18th century. They specialized in garmentfinishing and making fashion accessories and embellishments, or trained to become lacemakers in convents. This was a process of gradual liberation of women from the traditional role imposed on them at birth. Noble-class women also made lace, but as a form of pastime. They also received private home education, learned Italian and French and played a musical instrument. Every affluent household in Dalmatia owned a personal library and led a social and cultural life similar to people in the West (e.g. organizing concerts, theatre-going). Noble women could easily access fashion innovations owing to the intense market trade in main ports or during their personal travels through Italy, although only in the company of their husbands; this was also customary among Romanian women, as Constanţa Vintilă-Ghiţulescu describes in her chapter.

The newly emerged social class of affluent young women from mariners' families acquired fashion innovations and oriental style indirectly through male family members working as sailors and ship captains. 
Middle-class Dalmatian women were inspired by the trends among the nobility. However, they simultaneously developed their own dress code, based on autochthonous heritage fused with both eastern and western influences. These women gathered information on fashion innovations through fairs, whereas Turkish influences reached them indirectly through Bosnian traders. They commonly employed Venetian style (alla veneziana) in their choice of furniture and clothing, and ordered these artefacts from domestic artisans of various crafts.

\section{Conclusion}

In analyzing the historical and trading climate of 18 th-century Dalmatia, our intention was to illustrate how a rich market enabled the development of various fashion styles, which would soon become an indicator of social status as their use was restricted and imposed by sumptuary laws. Fashion influences, which determined the appearance of noblewomen, middle-class women, and their counterparts in the lower social classes, arrived both from the West and the Orient. Intensive production of lace in convents and domestic craftsmanship indicates the concern with appearance and fashion among women of all social classes, whereas the few preserved garments illustrate adherence to European fashion guidelines and demonstrate the precision and artistry of their manufacture. The observed portraits indicate the complex hallmarks of the period, such as the wearer's social status, fashion movements, and the manner in which particular garments and ornaments were worn, while preserved clothing artefacts display the cutting patterns used, the tactile delicacy of the fabric, the manufacturing technique and the intensity of their colours. Since Italy and France, in particular, were fashion arbiters of the period, the overview emphasizes the presence of Italian, French and English fashion terminology in 18th-century Dalmatia as another important indicator of adherence to European fashion guidelines by local noblewomen and affluent citizens in their clothing culture and daily rituals. The fashion innovations adopted correspond, with only a slight delay, to those which originated in fashion capitals like Venice, Paris, and London, thus making Dalmatia the equivalent of other urban European regions. The essential differences in status and clothing styles among the nobility, middle-class women, and commoners were observed in dress types, use of fabrics, and types of jewellery, as substantiated by archival records and preserved portraits.

Translated by Antonia Treselj 


\section{Bibliography}

Ashelford, Jane, The Art of Dress. Clothes through History 1500-1914 (London: 1996).

Bajić - Žarko, Nataša, Split kao trgovačko i tranzitno središte na razmeđu istoka i zapada u 18. stoljeću [Split as a Trade and Transit Centre at the Crossroads of East and West in the 18th Century] (Split: 2004).

Banić, Silvija, "Prilog poznavanju sakralnih inventara otoka Raba: najvrjedniji povijesni tekstili sačuvani na misnom ruhu i drugim dijelovima liturgijske opreme" [Contributions to the Understanding of the Sacred Inventory from The Island of Rab: the Most Valuable Historical Textiles Preserved as Mass Attire and Other Parts of Liturgical Equipment], Rapski zbornik II (Rab: 2012), 461-499.

Bašić, Đivo, "Pomorstvo Dubrovnika od XII. do početka XX. Stoljeća" [The Maritime Affairs of Dubrovnik from the 12th to the Beginning of the 2oth Century], Pomorski zbornik 44 [Maritime Anali 44] (Dubrovnik: 2006) 1, 139-177.

Benjamin, John, Antique Jewellery (Suffolk:2003).

Borders of Croatia on Maps from 12th-2oth Centuries, The Museum of Arts and Crafts (Zagreb: 1992).

Božanić-Bezić, Nevenka, "Prilog dubrovačkom umjetničkom vezivu XVI. Stoljeća" [The Contribution of Dubrovnik Embroidery from the 16th Century], Prilozi povjest umjetnosti u Dalmaciji 14 (Split:1962), 153-164.

Božanić-Bezić, Nevenka, “Tradicija čipkarse tehnike na otocima Hvaru i Visu od XVII stoljeća do danas" [Traditions of Lacemaking on the Islands of Hvar and Vis from the 17th century Onwards], Makedonskifolklor, god. XVIII, 35 (Skopje: 1985), 101-106.

Božanić-Bezić Nevenka, "Hvarske i viške u svjetlu arhivskih izvora od 16. do 18 stoljeća", [Archival Records from Hvar and Vis from the 16th-18th Centuries], Prilozi povijesti otoka Hvara, x (Hvar: 1997) 101-109.

Božanić-Bezić, Nevenka, Tragom renesansno-barokne čipke u dalmatinskim samostanima, [Renaissance and Baroque Lace in Dalmatian Monasteries], (Korčula: 1999), 109-117.

Božanić-Bezić, Nevenka, Juditini dvori [Judith's Chambers], (Split: 2001).

Božanić-Bezić, Nevenka, "Odijevanja u Hvaru u XVIIII stoljeću” [Dressing on the Island of Hvar in the 18th Century], Juditini dvori [Judith's Chambers], (Split: 2001), 187-203.

Božanić-Bezić, Nevenka, “Utjecaj pomorskih veza na kulturu življenja u Dalmaciji i Dubrovačkoj Republici od 15. do 19. stoljeća” [The Influence of Maritime Connections on the Culture of Life in Dalmatia and the Dubrovnik Republic in the $15^{\text {th }}$ and 19th Centuries], Juditini dvori [Judith's Chambers], (Split: 2001), 55-67.

Božanić-Bezić. Nevenka, "Prilog istraživanju čipke u Dalmaciji" [Contributions to the Research of Lace from Dalmatia], Središnji čipkarski tečaj u Beču (Lepoglava: 2002), $60-72$. 
Božanić-Bezić. Nevenka, “Čipka na odjeći u 18. stoljeću u srednjoj Dalmaciji” [Lace on Clothing from the 18th Century in Dalmatia], Čipka u kulturi tekstila i odijevanja (Lepoglava:2003), 9-17.

Božanić-Bezić, Nevenka, "Umjetnički dodiri dviju jadranskih obala u 17. i 18. Stoljeću" [Artistic Encounters Between Two Adriatic Coasts in the 17th and 18th Centuries], Zbornik radova (Split: 2007), 121-127.

Božić Bužančić, Danica, Privatni i društveni život Splita u osamnaestom stoljeću [The Private and Social life of Split in the 18th Century] (Zagreb: 1982).

Boucher, Francoise, A History Of Costume in the West (London: 1997).

Braudel, Fernand, Civilization and Capitalism, 15th-18th Centuries, Vol 1: The Structures of Everyday Life (London: 1981).

Campbell, Gordon (ed.), "Bizzare Silk", The Grove Encyclopedia of Decorative Arts, Volume I, (Oxford University Press: 2006), 113-114.

Car, Gordana, Pregled muških odijela druge polovice 18. stoljeća u Hrvatskoj [Review of Men's Suits from the Second Half of the 18th Century], Diplomski rad obranjen na Tekstilno- tehnološkom fakultetu u Zagrebu (12.05.2013.).

Celio Cega, Fani, Svakidašnji život grada Trogira od sredina 18. do sredine 19. stoljeća [The Daily Life of Trogir from the Mid-18th to Mid-19th century], (Split: 2005).

Chrisman-Campbell, Kimberly, "From Baroque Elegance to the French Revolution: 1700-1790 ", The Fashion Reader (Oxford: 2007), 6-20.

Craven Elizabeth, Letters from the Right Honourable Lady Craven, to his Serene Highness The Margrave of Anspach, During her Travels Through France, Germany and Russia in 1785 and 1786 (London: 1814).

Čoralić, Lovorka, "Prilog poznavanju prisutnosti i djelovanja hrvatskih trgovaca u Mlecima (15-18 stoljeća)" [Contributions to Knowledge of the Presence and Activities of Croatian Retailers in Venice (15th-18th Centuries)], Povijesni prilozi 22 (Zagreb: 2002) 41.-73.

Delpierre, Madeleine, Dress in France in the Eighteenth Century (New Haven: 1997).

Eckhel, Nerina, Lacemaking in Croatia (Zagreb: 2007).

Fisković, Cvito, "Putovanje na pelješkom jedrenjaku s kraja 18. i početka 19. stoljeća" [The Journey of Pelješac Sailing Boats from the Late 18th to Early 19th Centuries], Pomorski zbornik [Maritime Almanac], (Zagreb: 1962), $175^{2}$.

Fisković, Cvito, "Orebička ženska narodna nošnja" [The Female Folk Costume from Orebic], Pelješki zbornik I [Peljesac Almanac], (Split: 1976), 227-268.

Fortis, Alberto, Put po Dalmaciji [Travels into Dalmatia], (Split: 2004).

Frampton, Mary, The Journal of Mary Frampton: From the Year 1779 Until the Year 1846 (London: 1885).

Fukai, Akiko, "Rococo and Neoclassical Clothing", Revolution in Fashion; European Clothing, 1715-1815 (New York: 1989).

Gail, Marsh, 18th-Century Embroidery Techniques (Lewes: 2006). 
Ginsburg, Madeleine, Avril Hart and Valerie Mendes, Four Hundred Years of Fashion (London: 1984).

Gjukić-Bender, Vedrana, Zbirka portreta iz fundusa Kneževa dvora-muzejsko prezentacija, podrijetlo, putovi nabave [A Collection of Portraits from the Funds of the Rector's Palace in Dubrovnik] (Doktorska disertacija obranjena na Filozofskom fakultetu, Sveučilište u Zagrebu: 2012).

Goetz, Adrien and Joannis, Claudette, Jewels in the Louvre (Paris: 2008).

Gušić, Marijana, "Proučavanje čipkarske proizvodnje na Hvaru”, [The Study of Lace Production on Hvar] Ljetopis JAZU knj. 67, (Zagreb: 196o), 326-238.

Gušić, Marijana, "Zbirka čipaka sv. Marije u Zadru” [Laces from the Church Museum of Saint Marija in Zadar], Radovi Zavoda JAZU, vI-vII (Zadar: 1960), 81-96.

Gušić, Marijana "Uz pitanje dubrovačke čipke" [Questions about the History of Dubrovnik Lace], Anali Historijskog instituta u Dubrovniku, (Dubrovnik: 1952), 331-340.

Hart, Avril and Susan, North, Seventeenth and Eighteenth-Century Fashion in Detail (London: 2009).

Herkov, Zlatko, Povijest zagrebačke trgovine [The History of Trade in Zagreb] (Zagreb: 1987).

Horvat, Rudolf, Kaptolski cehovi u Zagrebu [Kaptol Guilds in Zagreb] (Zagreb: 1936).

Horvat, Rudolf, Povijest trgovine obrta i industrije u Hrvatskoj [The History of Trade, Crafts and Industry in Croatia] (Zagreb: 1994).

Hyde, Melissa, “The 'Makeup' of the Marquise: Boucher's Portrait of Pompadour at Her Toilette", The Art Bulletin, 82 (3). (London: 2000), 453-475.

Ivoš, Jelena, "Liturgijsko ruho" [Liturgical Vestments], Zbirka Tekstila Muzeja za Umjetnost i obrt (Zagreb : 2010).

Janeković Römer, Zdenka, Nasilje zakona: Gradska vlast i privatni život u kasno srednjovjekovnom i ranonovovjekovnom Dubrovniku [The Violence of Law: City Authorities and Private Life in Medieval and Early Modern Dubrovnik] (Dubrovnika: 2003).

Karaman, Igor, "Zagrebački trgovci u 17 i 18 stoljeću” [Merchants from Zagreb in the 17th and 18th Centuries], Historijski zbornik, god. XXIX-XXX, (Zagreb:1976-1978).

Lovrić, Ivan, Bilješke o putu po Dalmaciji opata Alberta Fortisa [Notes on Travels in Dalmatia], tabla v (Zagreb: 1948).

Marković Vladimir, Prijatelj-Pavičić Ivana, Umjetnički dodiri dviju jadranskih obala u 17. i 18. stoljeću [Artistic Encounters Between Two Adriatic Coasts in the 17th and 18th Centuries] (Split: 2003).

Markowsky, Barbara, Europaische Seidengewebe des 13.'14. Jahrhunderts (Koln: 1976). Ivan Milčetić, "Duhovne i šaljive pjesme iz Makarske" [Spiritual and Funny Songs from Makarska], Građa za povijest književnosti V [Archives of History for Literature v], (Zagreb: 1907), 163 . 
Mottola, Molfino, Alessandra and Maria Teresa Binaghi Olivari, I pizzi: moda e simbolo (Milano: 1977).

Novak, Grgo, Split u svjetskom prometu [Split as a Part of World Traffic] (Split: 1930).

Novak, Grgo, Povijest Splita [The History of Split] (Split: 1964).

Novak, Grga, Hvar kroz stoljeća [The Island of Hvar Through the Centuries] (Hvar: 1972), 130-133.

Pavelić, Vanda, Oblici odjeće [Types of Clothing] (Zagreb: 1955).

Ribeiro, Aileen, Facing Beauty: Painted Women \& Cosmetic Art (New Haven: 2011).

Sadako, Takeda, Sharon and Kaya, Durland, Spilker, Fashioning Fashion: European Dress in Detail 1700-1915 (Los Angeles: 2010).

Simončič, Katarina Nina, "Jacket-bodices from the End of the 17th Century-Analyses and Attributes", Book of Proceedings for the 7 th International Textile, Clothing \& Design Conference (Zagreb: 2014), 640-645.

Stojan, Slavko, U salonu Marije Giorgi Bona [In the Salon of Marija Giorgi Bona] (Dubrovnik: 1996).

Thepaut-Cabasset, Corinne, The Mouche, Beauty Patch. Innovation, Name and Reputation (2012) http://www.fashioningtheearlymodern.ac.uk/wordpress/wp-content/ uploads/2012/07/The-Mouche-Object-in-focus-final-textı.pdf.

Weber, Caroline, Queen of Fashion-What Marie Antoinette Wore to the Revolution (New York: 2007). 